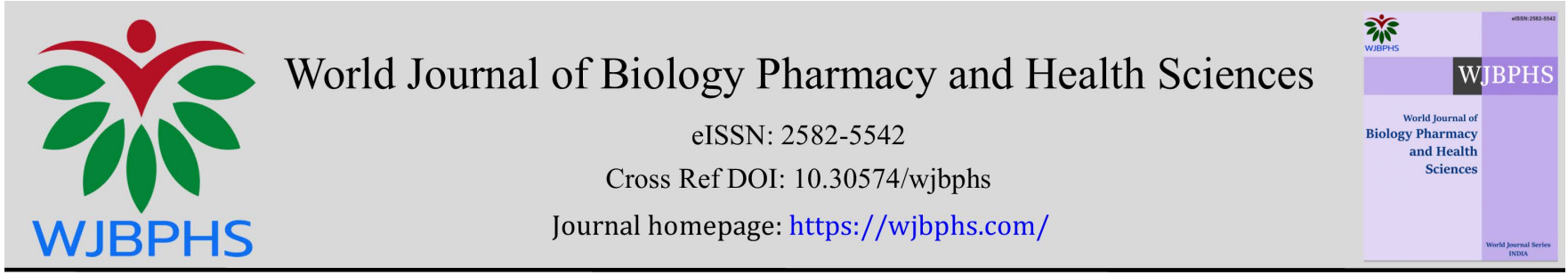

(RESEARCH ARTiCLE)

\title{
Morphological properties and chemical composition of three Calligonum species Growing-wild in Tunisian Desert: A chemotaxonomic study
}

\author{
Adel Dhief ${ }^{1,2, *}$, Sami Zouari ${ }^{1}$, Samira Aschi-Smiti 2 and Mohamed Neffati 1 \\ ${ }^{1}$ Institute of Arid Regions, Laboratory of Pastoral Ecology, 4119, Medenine, Tunisia. \\ 2 Department of Biology, Faculty of Sciences of Tunis, 1060, Tunis, Tunisia.
}

World Journal of Biology Pharmacy and Health Sciences, 2022, 09(01), 061-073

Publication history: Received on 11 December 2021; revised on 24 January 2022; accepted on 26 January 2022

Article DOI: https://doi.org/10.30574/wjbphs.2022.9.1.0023

\begin{abstract}
The essential oils of three wild species of Calligonum (C. azel, C. arich and C. comosum) growing in Tunisian desert were obtained by hydrodistillation and were analyzed in order to discern the differences and similarities between the volatiles chemical compositions of these species. A total of 110 compounds, which accounted for $93.95-99.68 \%$ of the total composition of the oils, have been identified. The main constituents were viridiflorol (9.59\%) in C. azel, palmitic acid $(20.06 \%)$ in C. arich and 9-Octadecenoic acid (19.76\%) in C. comosum. Morphological similarity study shows two groups: the first one contains C. azel and C. comosum and the second group is formed by C.arich. Based on their chemical composition, two chemotaxonomic groups may be established: C. azel on one hand, C. arich and C. comosum on the other hand. As a consequence, the morphological diversity of these species doesn't reflect their chemical polymorphism.
\end{abstract}

Keywords: Calligonum; Essential oil; Polygonaceae; Tunisian desert; Chemotaxonomic significance; Morphological character

\section{Introduction}

Desertification is a land degradation problem of major importance in the world's arid regions. Approximately, three quarters of Tunisia are arid and desert regions [1]. Virtually all of the rangeland has suffered severe land degradation. Erosion continues on the extensive dry farm lands and desertification effects are evident in the form of soil fertility, soil compaction, and soil crusting [2]. Characterised by low rainfall, high evapotranspiration, high temperature and desiccating winds, Tunisian desert was colonised by several endemic plants that are likely new crop candidates for these arid lands [3]. These plants, producing significant yields of relatively high valued products such as pharmaceuticals and biologically active materials like essential oils, have lower water requirement [4]. Polygonaceae family is a source of bioactive compounds; some species have medicinal properties and uses: Emex spinosa is purgative and diuretic, its boiled leaf was used by African tribes for the cure of dyspepsia and biliousness, and to stimulate appetite [5]. Rumex vesicarius is stomachic, diuretic and astringent. Its roasted seeds are eaten for the cure of dysentery and the plant juice is used to check toothache and nausea and to promote appetite [6]. In the south of Tunisia, Polygonum aviculare was used as astringent, antidiarrheic, vulneraire, hemostatic while Polygonum equisetiforme was used for the disinfection of Plaies, cicatrisant and fortifiant [7].

Calligonum genus belongs to the Polygonaceae family, with some 80 species distributed throughout Western Asia, Southern Europe and North Africa [8]. Only C. comosum L'Hérit, C. azel Maire and C. arich Le Houérou occur in the Tunisian arid zone and the last one is endemic [1]. The three Calligonum species are dominant perennials in active sand dunes and stabilized sand field in the southern desert of Tunisia and grow naturally in the eastern Great Erg [1]. In tunisian Desert, Cauvet show that $C$. comosum was served to the treatment of the scabies of the camel [9]. The decoction

\footnotetext{
${ }^{*}$ Corresponding author: Adel Dhief

Institute of Arid Regions, Laboratory of Pastoral Ecology, 4119, Medenine, Tunisia.
}

Copyright (@) 2022 Author(s) retain the copyright of this article. This article is published under the terms of the Creative Commons Attribution Liscense 4.0. 
of roots of this species was vermifuge [7]. In United Arab Emirates, Calligonum comosum is used by some healers to treat stomach ailments, the stems and leaves are chewed for curing toothache [10]. The fresh aerial parts of this species, collected from Abu Dhabi Emirates, show an anti-inflammatory and antiulcer activity [11]. Some compounds, extracted from Calligonum comosum L. growing in Egypt, present a cytotoxic and antioxidant activity [12]. Till date there has been scarce information about the morphological studies of Calligonum comosum [13].

In the Tunisian desert, the taxonomy of the Calligonum genus was described several times $[1,3,7,14-15]$ The Results of the recent study [15] show highlight differences in phenological and morphological patterns of the three Calligonum shrubs (C. arich, C. azel and C. comosum) that typically establish at different positions on dune crests, slopes and valley, respectively. To the best of our knowledge, there are no reports in the literature concerning the extraction of essential oils from the three Calligonum species growing in Tunisia. Therefore, the aim of the present work is to characterize the volatile constituents, extracted by hydrodistillation, from the aerial parts of $C$. comosum, $C$. azel and $C$. arich collected at the flowering stage and to search an eventual correlation between the chemical and the morphological polymorphism of the three studied species.

\section{Material and methods}

\subsection{Plant materials}

The aerial parts (green branches and flowers) of C. comosum, C. azel and C. arich were collected from the eastern Great Erg of Tunisia near the petrol station of El Borma (31 $36^{\prime} \mathrm{N}, 09^{\circ} 27^{\prime} \mathrm{E}$, at 231 and $277 \mathrm{~m}$ asl) at the flowering stage (March-April 2009) and identified according to the "Flore de la Tunisie" [16]. The studied site (El Borma) was dominated by $C$. azel, $C$. arich and $C$. comosum beside others species such as Cleome arabica, Cornulaca monocantha, Euphorbia gugoniana, Helianthemum confertum, Retama raetam, Spartium saharae, Ephedra alata, Astragalus gombiformis and Stipagrostis pungens [15]. Three samples of each Calligonum species were deposited at the herbarium of the Institute of Arid Areas in Medenine for chemical analysis (Tunisia).

\subsection{Morphological study}

Measurements of the different morphological traits were recorded on 10 plants for each species. Plant length and width, fruits length and diameter of each species were determined using a meter and a graduated ruler respectively. Also, nodes and internodes were determined using a digital calliper and a graduated ruler, respectively. Colour, aspect identification was also dealt for flowers, stems, anthers and stigmas. Number of anthers and stigmas has been examined by optic microscope. Other morphological traits were also recorded such as flowering and fruiting time (Table1).

Table 1 Morphological traits studied in the three Calligonum species

\begin{tabular}{|l|c|c|c|}
\hline \multirow{2}{*}{ Morphological traits } & \multicolumn{2}{|l|}{ Measurements (cm) } \\
\cline { 2 - 4 } & C. comosum & C. azel & C. arich \\
\hline Plant length & $75-220(147.5)$ & $350-550(450)$ & $430-810(620)$ \\
\hline Plant width & $70-120(95)$ & $260-340(300)$ & $450-650(550)$ \\
\hline Old stem color & Grayish white & Grayish white & Brown \\
\hline Green stem aspect & Rough & Smooth & Smooth \\
\hline Inter-node length & $2.2-6.8(4.5)$ & $3.4-9.6(6.5)$ & $5.2-12.8(9)$ \\
\hline Nodes width & $0.07-0.20(0.135)$ & $0.10-0.35(0.225)$ & $0.10-0.45(0.275)$ \\
\hline Flower color & White & White & Red \\
\hline Anthers color & Red & White & White \\
\hline Stigmas color & Rose & White & White \\
\hline Anthers number & 12 & 16 & 14 \\
\hline Stigmas number & 4 & 4 & 4 \\
\hline Flowering time & Middle march & End march & End april \\
\hline
\end{tabular}




\begin{tabular}{|l|c|c|c|}
\hline Fruit length & $0.7-0.9(0.8)$ & $1.0-1.2(1.1)$ & $1.2-1.4(1.3)$ \\
\hline Fruit diameter & $0.25-0.45(0.35)$ & $0.26-0.50(0.38)$ & $0.21-0.35(0.28)$ \\
\hline Fruit hairs length & $0.15-0.35(0.25)$ & $0.11-0.27(0.19)$ & $0.20-0.40(0.30)$ \\
\hline Fruit color & Brown & Brown & mallow \\
\hline Fruiting time & First april & Midd april & Mid may \\
\hline
\end{tabular}

\subsection{Essential oil extraction}

The aerial parts of each sample were air dried for 15 days and submitted to hydro distillation for $4 \mathrm{~h}$, in a Clevengertype apparatus [17]. $\mathrm{n}$-Hexane $(2 \mathrm{ml})$ was used as the collector solvent [18]. After evaporation of the solvent under $\mathrm{N}_{2}$ flow, the essential oil was dried over anhydrous sodium sulphate and stored in sealed vials protected from the light at $20^{\circ} \mathrm{C}$ before analyses. Three oil samples for each species were analyzed by GC-FID and GC-MS.

\subsection{Essential oil analysis}

\subsubsection{Gas chromatography}

A Hewlett-Packard 5890 series II gas chromatograph equipped with HP-5MS capillary column (30 m x 0.25 mm i.d., film thickness $0.25 \mu \mathrm{m}$; Hewlett-Packard) and connected to a flame ionization detector (FID) was used. The column temperature was programmed at $50{ }^{\circ} \mathrm{C}$ for $1 \mathrm{~min}$, then $7{ }^{\circ} \mathrm{C} / \mathrm{min}$ to $250{ }^{\circ} \mathrm{C}$ for $5 \mathrm{~min}$, split: $1 / 60$.. The injection port temperature was $240{ }^{\circ} \mathrm{C}$ and that of the detector $250^{\circ} \mathrm{C}$. The carrier gas was helium (99.995\% purity) at a constant flow of $1.2 \mathrm{ml} / \mathrm{min}$. The analysis was performed on $2 \mu \mathrm{l}$ volume of each sample. Percentages of the constituents were calculated by electronic integration of FID peak areas, without the use of response factor correction. Retention indices (RI) were calculated for separate compounds relative to $\mathrm{C}_{8}-\mathrm{C}_{26} \mathrm{n}$-alkanes mixture (Aldrich Library of chemicals standards) [19].

\subsubsection{Gas chromatography - Mass spectrometry (GC/MS)}

The isolated volatile compounds were analysed by GC/MS, using a Hewlett-Packard 5890 series II gas chromatograph. The fused HP-5MS capillary column (the same as that used in the GC analysis) was coupled to a HP 5972A masseselective detector (Hewlett-Packard, Palo Alto, CA, USA). The oven temperature was programmed from $50^{\circ} \mathrm{C}(1 \mathrm{~min})$ to $250{ }^{\circ} \mathrm{C}(5 \mathrm{~min})$ at $7{ }^{\circ} \mathrm{C} / \mathrm{min}$. The temperature of the injector port was held at $250^{\circ} \mathrm{C}$, split: $1 / 100$, the temperature of the detector was set at $280^{\circ} \mathrm{C}$. The carrier gas was helium (99.995\% purity), with a flow rate of $1.2 \mathrm{ml} / \mathrm{min}$ and the analysed sample volume was $2 \mu \mathrm{l}$. The mass spectrometer (MS) conditions were as follow: ionization voltage, $70 \mathrm{eV}$; ion source temperature, $150^{\circ} \mathrm{C}$; electron ionization mass spectra were acquired over the mass range $50-550 \mathrm{~m} / \mathrm{z}$.

\subsubsection{Volatile compounds identification}

The essential oil compounds of were identified by comparing the mass spectra data with spectra available from the Wiley 275 mass spectra libraries (software, D.03.00). Further identification confirmations were made referring to retention indices (RI) data generated from a series of known standards of n-alkanes mixture ( $\mathrm{C}_{8}-\mathrm{C}_{26}$ ) (Aldrich Library of chemicals standards) [19] and to those previously reported in the literature [20-28].

\subsection{Cluster analysis}

The cluster analysis (morphological traits and the identified chemical compounds) was based on similarity matrix and implemented according to the NTSYS software's WPGMA cluster (Weighed Pair Group Method using Arithmetic Average).

\section{Results and discussion}

\subsection{Morphological study}

The morphological traits of the three Calligonum species were shown in Table 1. This table and fig.1, shows that the size, both length and width, differ among species: $C$. arich is the taller and the larger while $C$. comosum is the shorter and the smaller (fig. 1). C. arich old stems are brown but $C$. azel and $C$. comosum have the same old stems colour: grayish white (fig.1). $C$. azel and $C$. arich green stems are smooth with an inter-node length reaching 9.6 and $12.8 \mathrm{~cm}$, respectively 
whereas C. comosum green stems is rough with an inter-node length reaching $6.8 \mathrm{~cm}$ (fig. 2). C. arich and C. azel nodes are generally swollen ( 0.1 to $0.45 \mathrm{~cm}$ width) while $C$. comosum nodes are slightly larger.
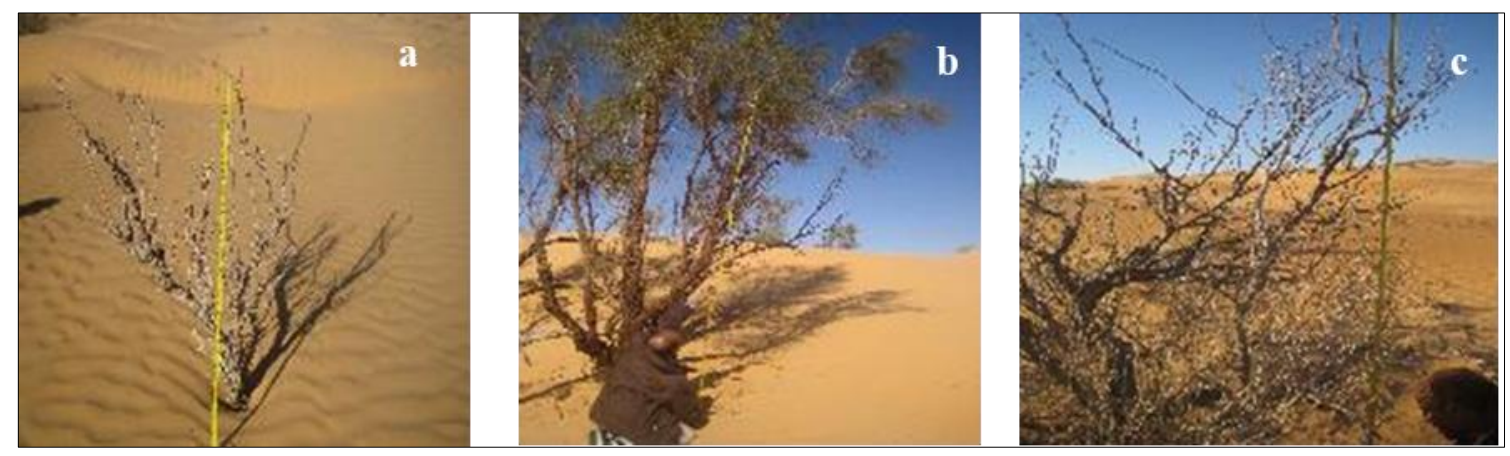

Figure 1 Length and width of the Calligonum species: C. comosum (a), C. arich (b), C. azel (c)

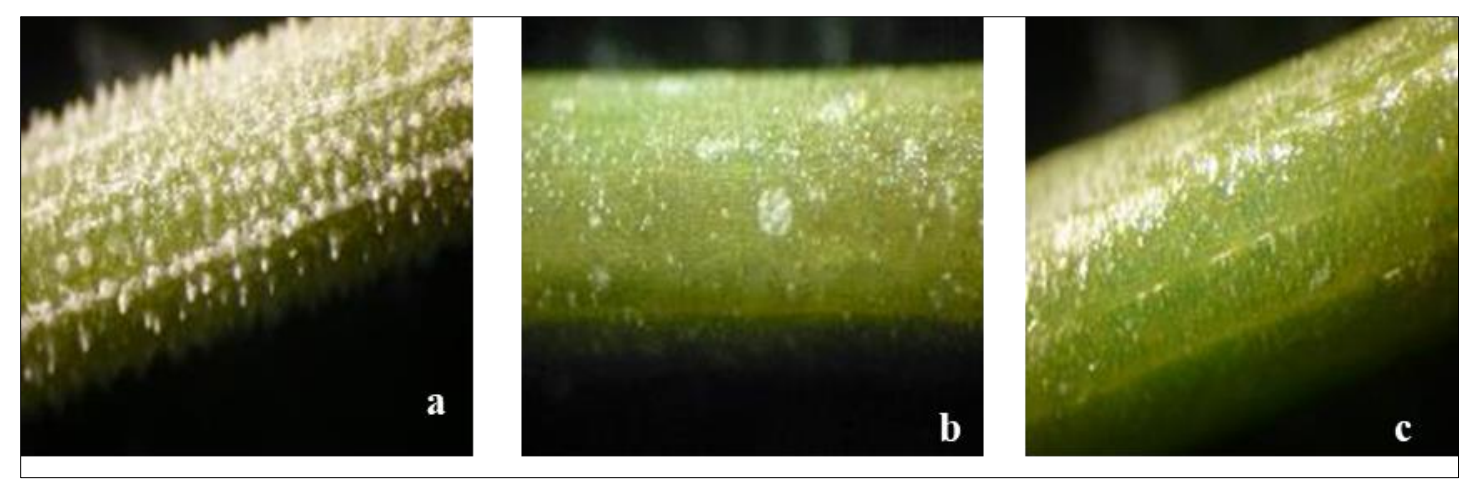

Figure 2 Green stems aspects of the Calligonum species: C. comosum (a), C. arich (b), C. azel (c)

Generally, flowering time for C. azel and C. comosum is recorded in March and delayed about one month for C. arich. The flower colour is white for C. azel and C. comosum and red for C. arich (fig. 3). The three flower species possess the same number of stigmas (4) but differ in anthers number (12 for C. comosum, 16 for C. azel and 14 for C. arich) (fig. 3). Stigmas and anthers of $C$. arich and $C$. azel are white while $C$. comosum have red anthers and rosy stigmas (fig. 4).
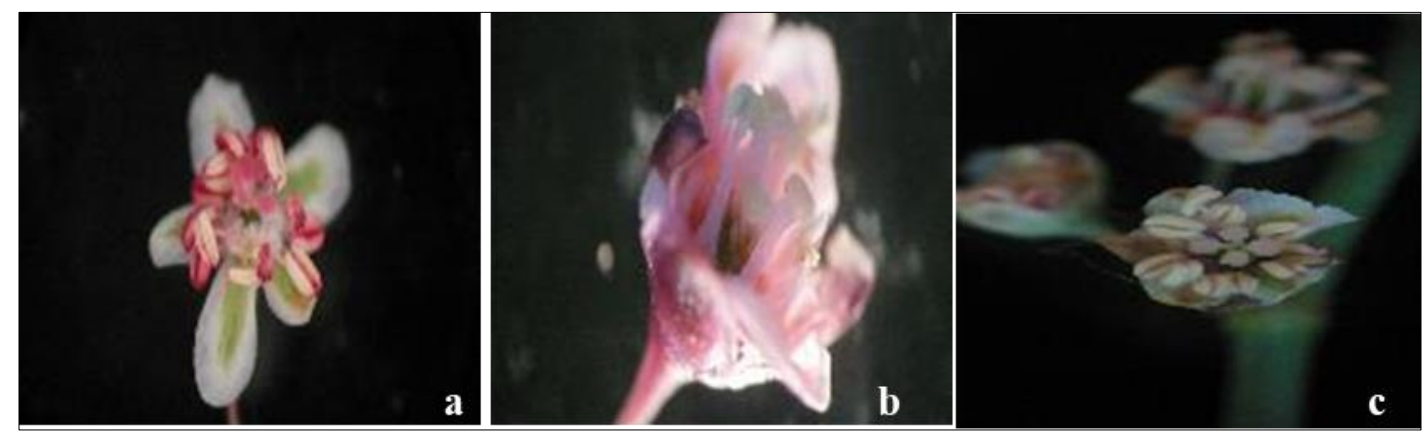

Figure 3 The flower color of the Calligonum species: C. comosum (a), C. arich (b), C. azel (c)

For the three Calligonum species, fruiting time follows the flowering time two weeks later. The fruits length of all species is about one $\mathrm{cm}$ with a brown color for $C$. azel and C. comosum and a mallow colour for C. arich (fig. 5). All fruits are rectangular with longitudinal rows of hairs which have a length about $3 \mathrm{~mm}$ (fig. 6). 

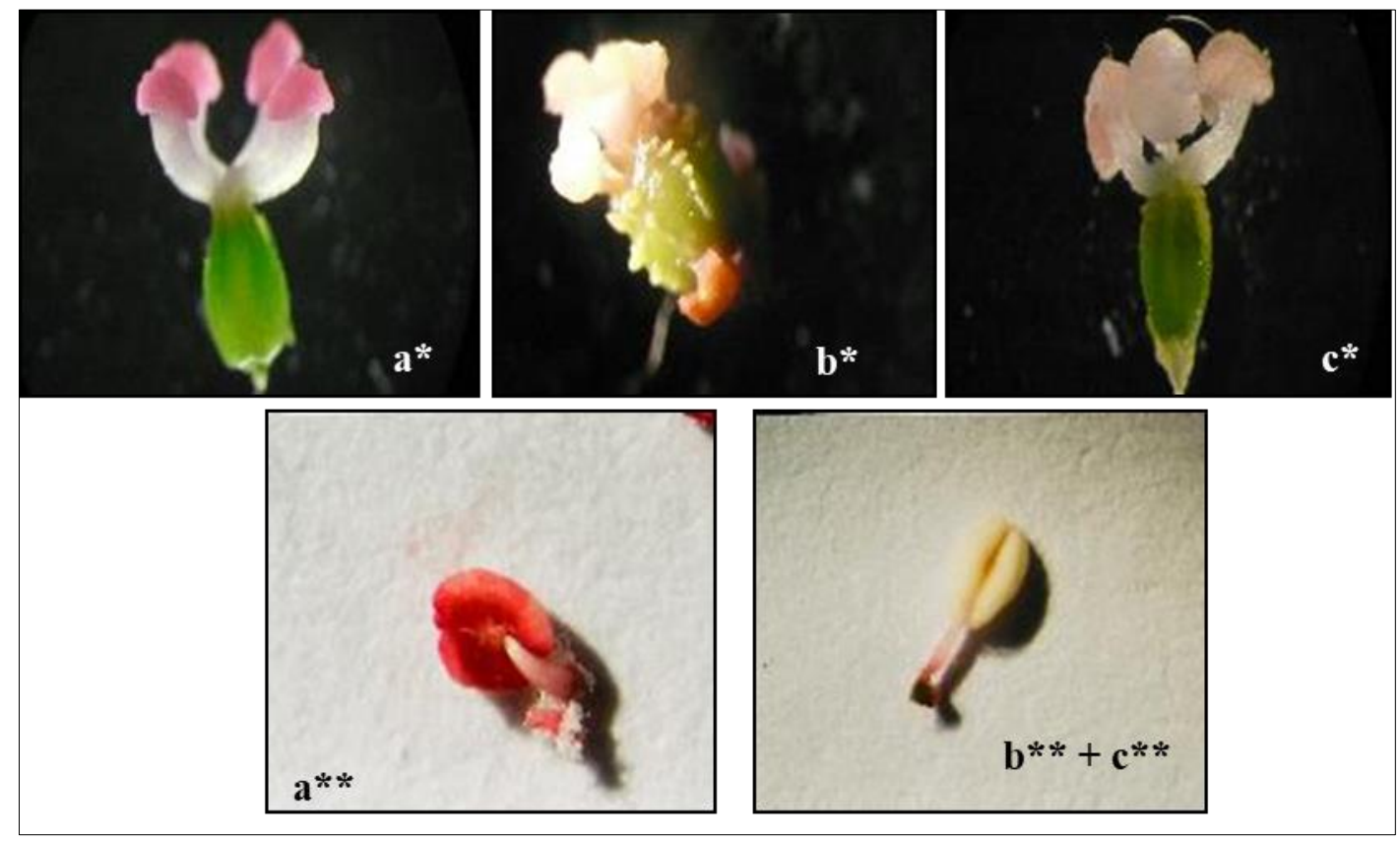

Figure 4 Stigmas* and anthers** of the Calligonum species: C. comosum (a), C. arich (b), C. azel (c)
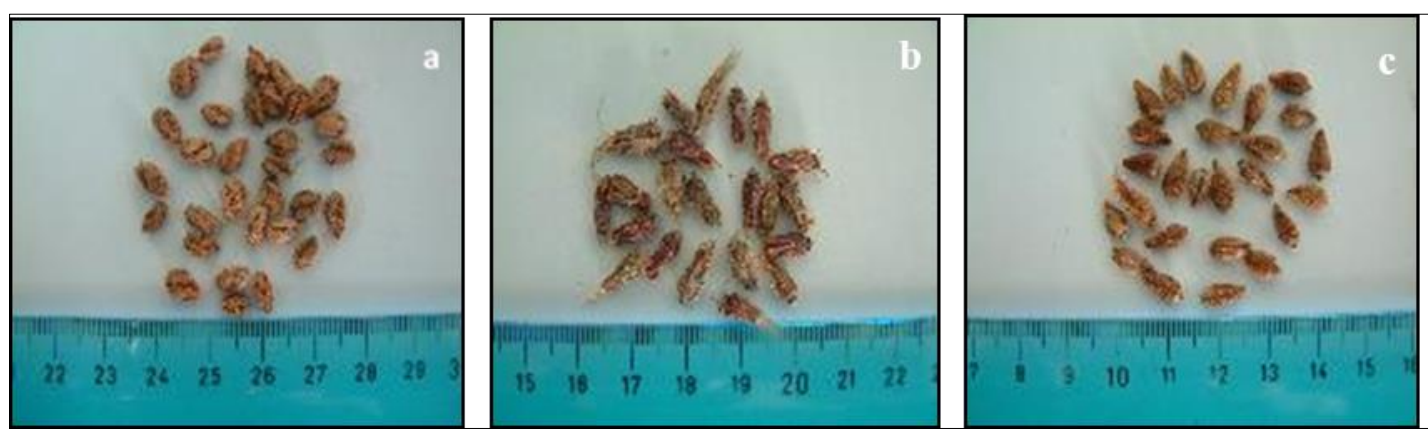

Figure 5 The fruits length and color of the Calligonum species: C. comosum (a), C. arich (b), C. azel (c)
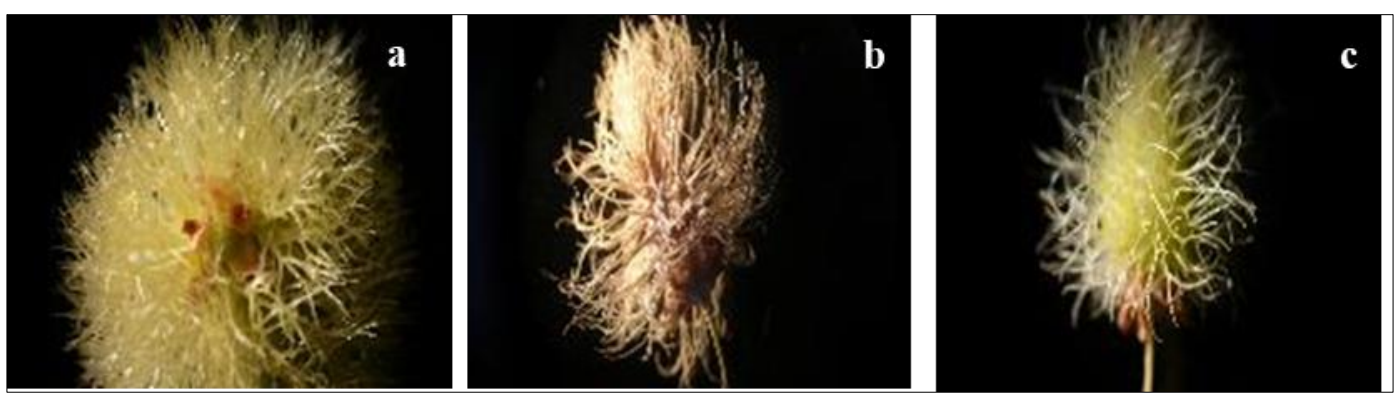

Figure 6 Fruit hairs length of the Calligonum species: C. comosum (a), C. arich (b), C. azel (c)

Morphological traits were also used to study the similarity between the three species. The dendrogram obtained in the cluster analysis of these morphological traits showed two groups (Fig. 7). The first is composed by C. Comosum and $C$. azel with a similarity of $29 \%$ as they share some morphological traits (Stem, flower and fruit colour). The second consists of $C$. arich with a similarity of $15 \%$. 


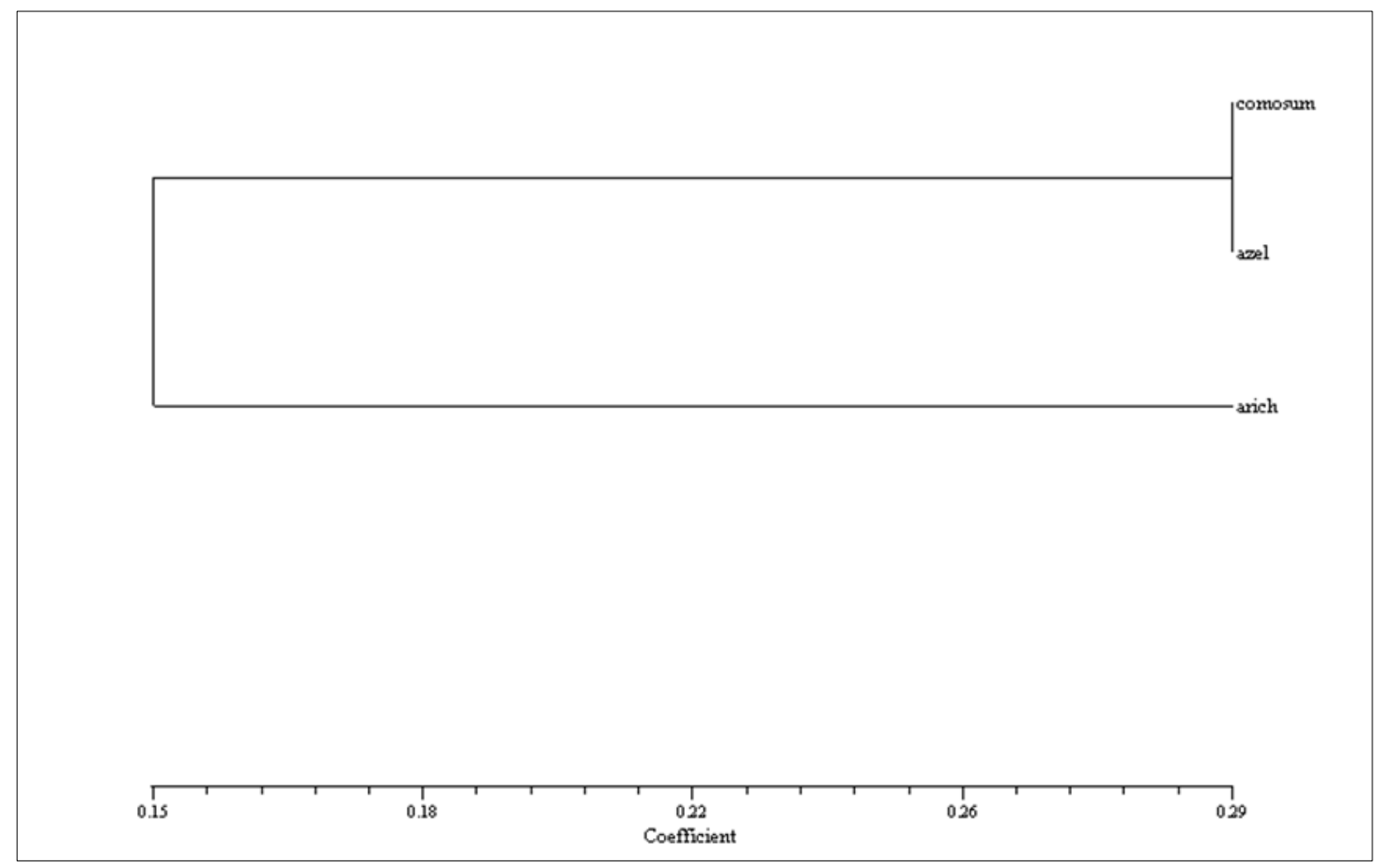

Figure 7 Dendrogram obtained in the cluster analysis of some morphological traits based on "WPGMA" method

\subsection{Essential oils composition}

The essential oils of the three species of Calligonum were obtained by hydrodistillation during the flowering phase (March-April 2009). The identified oil components from these three species (C. arich, C. azel and C. comosum,), representing 96.71\% (19 compounds), 93.95\% (64 compounds) and 99.68\% (36 compounds) of the total oils, are listed in table 2 in order of their elution on the HP-5MS column. This table includes also their retention indices and the percentage composition.

Table 2 Essential oil composition of the aerial parts of three Calligonum species growing in Tunisian desert

\begin{tabular}{|c|c|c|c|c|c|}
\hline & & & $\%^{c}$ & & \\
\hline & Compounds ${ }^{a}$ & $\mathbf{R} \mathbf{I}^{\mathbf{b}}$ & C. & C. & C. \\
\hline 1 & Hexanal & 804 & 0.68 & 2.82 & 0.44 \\
\hline 2 & trans-2-hexenal & 858 & 0.36 & 1.30 & - \\
\hline 3 & Heptanal & 905 & - & 0.13 & 0.42 \\
\hline 4 & $\alpha$-pinene & 938 & 0.66 & - & - \\
\hline 5 & Camphene & 952 & 0.18 & - & - \\
\hline 6 & Sabinene & 977 & 0.15 & - & - \\
\hline 7 & $\beta$-pinene & 980 & 0.16 & - & - \\
\hline 8 & 6-Methyl-5-hepten-2-one & 992 & - & - & 0.10 \\
\hline 9 & $\alpha$-terpinene & 102 & 0.29 & - & - \\
\hline 10 & $o$-cymene & 102 & - & 0.14 & - \\
\hline 11 & $p$-cymene & 102 & 0.17 & - & - \\
\hline 12 & Limonene & 103 & 0.15 & - & - \\
\hline 13 & 1.8-Cineole & 103 & 0.15 & - & - \\
\hline 14 & trans- $\beta$-ocimene & 105 & 0.35 & - & - \\
\hline 15 & $\gamma$-terpinene & 106 & 1.14 & 1.32 & 0.11 \\
\hline 16 & $\alpha$-terpinolene & 109 & 0.26 & - & - \\
\hline 17 & Linalool & 110 & 0.14 & - & - \\
\hline
\end{tabular}




\begin{tabular}{|c|c|c|c|c|c|}
\hline 18 & Nonanal & 110 & 0.23 & 0.42 & 0.79 \\
\hline 19 & $\beta$-thujone & 111 & - & - & 0.32 \\
\hline 20 & Camphor & 114 & 0.36 & - & 0.14 \\
\hline 21 & Cyclooctanone & 115 & - & - & 1.02 \\
\hline 22 & Borneol & 117 & 0.32 & - & - \\
\hline 23 & Unidentified & 117 & - & - & 0.80 \\
\hline 24 & 4-Terpineol & 118 & 0.63 & - & - \\
\hline 25 & $\beta$-Cyclocitral & 122 & - & 0.13 & \\
\hline 26 & Unidentified & 123 & - & - & 0.38 \\
\hline 27 & Methyl thymyl ether & 123 & 0.42 & 0.86 & - \\
\hline 28 & Linalyl acetate & 125 & 0.17 & - & - \\
\hline 29 & Chrysantenyl acetate & 126 & - & - & 5.27 \\
\hline 30 & Vitispirane & 128 & 0.29 & 5.94 & - \\
\hline 31 & Bornyl acetate & 128 & 1.06 & - & - \\
\hline 32 & Sabinyl acetate & 129 & - & - & 3.77 \\
\hline 33 & Carvacrol & 130 & 0.49 & 10.46 & - \\
\hline 34 & 1-Butyl-1H-1.2.4-triazole & 131 & - & - & 0.36 \\
\hline 35 & Unidentified & 133 & - & - & 1.93 \\
\hline 36 & Bicycloelemene & 134 & 0.57 & - & 0.27 \\
\hline 37 & Unidentified & 136 & - & - & 0.23 \\
\hline 38 & $\alpha$-Copaene & 138 & 1.15 & - & - \\
\hline 39 & $\beta$-Bourbonene & 139 & 0.4 & - & - \\
\hline 40 & $\beta$-Elemene & 139 & 1.45 & - & - \\
\hline 41 & Unidentified & 140 & 1.07 & - & - \\
\hline 42 & $\alpha$-Gurjunene & 141 & 3.41 & - & - \\
\hline 43 & trans-Caryophyllene & 142 & 4.01 & - & 0.25 \\
\hline 44 & (E)-Geranyl acetone & 145 & - & 0.17 & - \\
\hline 45 & $\alpha$-Humulene & 146 & 0.42 & - & - \\
\hline 46 & Unidentified & 146 & - & - & 0.5 \\
\hline 47 & allo-Aromadendrene & 146 & 1.66 & - & - \\
\hline 48 & $\alpha$-amorphene & 148 & 0.37 & - & 0.14 \\
\hline 49 & $\beta$-Ionone & 149 & - & 0.63 & - \\
\hline 50 & Germacrene D & 149 & 4.46 & - & 3.54 \\
\hline 51 & Aromadendrene & 149 & 0.74 & - & - \\
\hline 52 & Bicyclogermacrene & 150 & 2.47 & - & 3.35 \\
\hline 53 & Eremophilene & 151 & 0.64 & - & - \\
\hline 54 & Davana-ether & 152 & - & - & 10.76 \\
\hline 55 & $\gamma$-Cadinene & 152 & 5.71 & - & - \\
\hline 56 & $\delta$-Cadinene & 153 & 2.29 & - & 0.45 \\
\hline 57 & $\beta$-Bisabolene & 154 & 1.78 & - & - \\
\hline 58 & $\alpha$-Calacorene & 154 & 0.24 & - & - \\
\hline 59 & Elemol & 156 & 6.94 & - & - \\
\hline 60 & Nerolidol & 156 & - & - & 0.74 \\
\hline 61 & Lauric acid & 157 & - & 1.78 & 0.27 \\
\hline 62 & Palustrol & 158 & 0.58 & - & - \\
\hline 63 & Cis-Davanone & 159 & - & - & 2.31 \\
\hline 64 & Caryophyllene oxide & 159 & 4.38 & - & - \\
\hline 65 & Diethyl phthalate & 159 & - & 15.36 & 3.5 \\
\hline
\end{tabular}




\begin{tabular}{|c|c|c|c|c|c|}
\hline 66 & Viridiflorol & 161 & 9.59 & - & 0.31 \\
\hline 67 & epi-Globulol & 161 & 1.55 & - & - \\
\hline 68 & Naphthalene. 1. 2. 3. 4. 4a. 7-hexhydro-1.6-dimethyl-4-(1- & 162 & 1.08 & - & - \\
\hline 69 & Dillapiole & 163 & - & 17.47 & 1.32 \\
\hline 70 & Unidentified & 163 & 1.36 & - & - \\
\hline 71 & Unidentified & 164 & - & - & 0.38 \\
\hline 72 & $\beta$-eudesmol & 164 & 4.66 & - & - \\
\hline 73 & Unidentified & 165 & - & - & 1.72 \\
\hline 74 & 2-Isopropyl-5-methyl-9-methylene-bicyclo[4.4.0]dec-1-ene & 165 & 7.61 & - & - \\
\hline 75 & $\tau$-Muurolol & 166 & - & - & 0.77 \\
\hline 76 & $\alpha$-Eudesmol & 167 & 8.33 & - & - \\
\hline 77 & 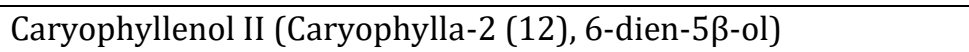 & 167 & 0.3 & - & - \\
\hline 78 & Unidentified & 167 & - & - & 0.26 \\
\hline 79 & Unidentified & 168 & - & - & 0.59 \\
\hline 80 & Cadalene & 168 & 0.48 & - & - \\
\hline 81 & Vulgarol B & 170 & - & - & 0.53 \\
\hline 82 & 14-Norcadin-5-en-4-one & 170 & 0.54 & - & - \\
\hline 83 & Valerenol & 172 & 0.68 & - & - \\
\hline 84 & Unidentified & 172 & - & - & 0.28 \\
\hline 85 & Cadina-4.10 (15)-dien-3-one & 175 & 0.79 & - & - \\
\hline 86 & Myristic acid & 176 & - & 1.15 & 0.50 \\
\hline 87 & Hexadecanal & 181 & - & - & 0.26 \\
\hline 88 & 6.10.14-Trimethylpentadeca-2-one & 184 & - & - & 0.18 \\
\hline 89 & Di-isobutylphthalate & 186 & 0.36 & 2.27 & 0.66 \\
\hline 90 & Hexadecanol & 187 & - & - & 0.21 \\
\hline 91 & Nonadecane & 188 & 0.12 & - & - \\
\hline 92 & Unidentified & 191 & - & - & 0.41 \\
\hline 93 & 15-Hexadecanolide & 193 & - & - & 0.75 \\
\hline 94 & Palmitic acid & 195 & - & 20.06 & 15.04 \\
\hline 95 & (Z)-9.17-Octadecadienal & 197 & - & - & 0.26 \\
\hline 96 & 13-Octadecenal & 198 & - & - & 0.41 \\
\hline 97 & Eicosane & 199 & - & - & 0.20 \\
\hline 98 & 1-Heneicosene & 208 & 0.25 & - & 0.45 \\
\hline 99 & Heneicosane & 210 & 1.43 & - & 0.44 \\
\hline 100 & $\gamma$-Palmitolactone & 211 & - & - & 0.13 \\
\hline 101 & Phytol & 212 & 0.35 & - & 0.85 \\
\hline 102 & (Z)-9-Octadecenoic acid & 215 & - & - & 19.76 \\
\hline 103 & Ethyl linoleate & 216 & 0.17 & 14.29 & - \\
\hline 104 & Octadecanoic acid & 217 & - & - & 1.26 \\
\hline 105 & 9-Tricosene & 228 & 0.28 & - & 0.36 \\
\hline 106 & Tricosane & 230 & - & - & 2.74 \\
\hline 107 & 9-Octadecenamide & 237 & - & - & 0.44 \\
\hline 108 & Unidentified & 248 & - & - & 2.51 \\
\hline 109 & Pentacosane & 250 & 0.47 & - & 1.41 \\
\hline 110 & Glycerol. 2-hexadecanoate & 252 & - & - & 2.41 \\
\hline \multirow[t]{3}{*}{ Tota } & & & 93.95 & 96.71 & 99.68 \\
\hline & Grouped components (\%) & & & & \\
\hline & Hydrocarbons and functionalised hydrocarbons & & 4.35 & 59.75 & 54.13 \\
\hline
\end{tabular}




\begin{tabular}{|c|c|c|c|}
\hline Monoterpene hydrocarbons & 3.51 & 1.46 & 0.11 \\
\hline Oxygenated monoterpenes & 2.66 & 0.13 & 9.50 \\
\hline Sesquiterpenes hydrocarbons & & & \\
\hline Naphthalene sesquiterpenes & 19.33 & - & 0.59 \\
\hline Azulene sesquiterpenes & 2.4 & - & - \\
\hline Others sesquiterpenes hydrocarbons & 19.21 & - & 7.41 \\
\hline Oxygenated sesquiterpenes & & & \\
\hline Oxygenated Naphthalene sesquiterpenes & 14.32 & - & 0.77 \\
\hline Oxygenated Azulene sesquiterpenes & 11.72 & - & 0.31 \\
\hline Others oxygenated sesquiterpenes & 12.76 & 5.94 & 14.34 \\
\hline Diterpenes & 0.35 & - & 0.85 \\
\hline Phenolic derivatives & 0.91 & 11.32 & - \\
\hline Arylpropanoids & - & 17.47 & 1.32 \\
\hline Miscellaneous compounds & - & 0.63 & - \\
\hline Nitrogeneous compounds & - & - & 0.36 \\
\hline Unidentified & 2.43 & - & 9.99 \\
\hline
\end{tabular}

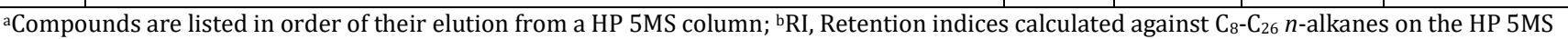
column; cPercentages obtained by FID peak-area normalization ; values represent an average of three determination

The isolated essential oils of each specie were complex mixture of mainly functionalised hydrocarbons (acids, esters, aldehydes ...), monoterpenes, sesquiterpenes, arylpropanoids and Phenolic derivatives: a total of 110 component were identified from which only four compounds (hexanal, gamma terpinene, nonanal and diisobutylphthalate) are common for the three oils with a relatively low rates.

The chemotypes of the investigated essentials oils of Calligonum species are the following: in $C$. azel: alpha eudesmol (8.33\%) and viridiflorol (9.59\%); in C. arich: carvacrol (10.46\%), ethyl linoleate (14.29\%), diethyl phthalate (15.36 $\%)$, dillapiole (17.47 \%) and palmitic acid (20.06 \%) and in C. comosum: davana ether (10.76\%), palmitic acid (15.04 $\%)$ and (Z)-9-Octadecenoic acid (19.76\%).

Comparing the chemical composition of the three oils within the same section many similarities are obvious. Hence, the oil of $C$. azel was characterized by a very large presence of terpenoids mainly sesquiterpenes hydrocarbons (40.94 \%) and oxygenated sesquiterpenes (38.8\%) while the oil of $C$. comosum contain less amount of terpenoids mainly monoterpenes (9.61\%) and sesquiterpenes (33.42\%). In contrast, the main similarities among C. arich and $C$. comosum in their composition are related to the high percentages of hydrocarbons and functionalised hydrocarbons $(59.75 \%$ and $54.13 \%$, respectively), palmitic acid was found to be a major compound in both oil and could be used as a chemotaxonomic tool for the characterization of others Calligonum species. Among this class, $(Z)$-9-Octadecenoic acid $(19.76 \%)$ and ethyl linoleate (14.29\%) were assigned as the main component in C. arich and C. comosum, respectively.

In addition, the essential oil of $C$. arich presents a relatively high percentage of phenolic derivatives (11.32 \%) and arylpropanoid (17.47\%). The last one was represented only by dillapiole which was considered as a larvicidal phytochemical compound [29]. Dillapiole could be also used for therapheutical purposes, particularly in the treatment of dermatophytosis [30]. Considered as a main component in the essential oil of $C$. arich, dillapiole was found only with a low rate in the essential oil of $C$. comosum (1.32\%). Although Carvacrol was found in a small percentage in the essential oil from aerial parts of $C$. azel $(0.49 \%)$, this phenolic derivative compound was reported as a major constituent in the oil of $C$. arich $(10.46 \%$ ) and was not been detected in C. comosum oil. This compound possessed high levels of antimicrobial activity [31].

The monoterpenes and sesquiterpenes distribution in these oils showed some differences. In fact, the monoterpenes hydrocarbon class was nearly represented in similar way in all cases but $C$. comosum oil contains much more oxygenated monoterpenes such as camphor. Detected only in the C. comosum oil, the two main compounds of oxygenated monoterpenes, were chrysantenyl acetate (5.94\%) and sabinyl acetate (3.77 \%). Sesquiterpenes hydrocarbons were absent in $C$. arich and present in low amount in $C$. comosum (8\%) whereas $C$. azel is rich in sesquiterpenes hydrocarbons (40.94\%). Among this class, the naphthalene and others hydrocarbons sesquiterpenes were present in almost equal percentage (19.33\% and $19.21 \%$, respectively) in C. azel in which $\gamma$-Cadinène $(5.71 \%)$ and germacrene $\mathrm{D}(4.46 \%)$ were assigned as the main hydrocarbons sesquiterpenes. 
The percentage of oxygenated sesquiterpene was approximately twice more important in the essential oil of C. azel $(38.8 \%)$ than that of $C$. comosum (15.42 \%). In particular, davana ether $(10.76 \%)$ was found as the main oxygenated sesquiterpenes in $C$. comosum while viridiflorol $(9.59 \%)$ and $\alpha$-eudesmol $(8.33 \%)$ were the major oxygenated sesquiterpenes in $C$. azel which could be considered as the chemotype of this oil. On the contrary, the oxygenated sesquiterpene compounds were present in a relatively smaller proportion (5.94\%) in C. arich. Absent in the arich oil, the diterpene class was identified only with a very low rate in C. azel (0.35\%) and C. comosum (0.85\%).

As described in the literature [13], the fresh flowers of $C$. comosum can be eaten as it is high in sugar and nitrogeneous components. This class was identified in our C. comosum oil and was presented by 1-butyl-1H-1,2,4-triazole.

\subsection{Cluster analysis of chemical compounds}

The cluster analysis of the chemical compound descriptors was shown as a dendrogram indicating the estimated relations between the three species of Calligonum (Fig. 8). The dendrogram obtained showed two groups. The first one is formed by $C$. arich and $C$. comosum with a similarity of $38 \%$ when using all chemical compound identified descriptors. However, using only major compound the similarity was only $30 \%$. These similarity percentages are low to consider $C$. arich and $C$. comosum as similar. This low similarity could be explained by the fact that Carvacrol was reported as a major constituent in the oil of $C$. arich (10.46\%) and absent in $C$. comosum oil. Besides, sesquiterpenes hydrocarbons compounds were absent in $C$. arich and present in low amount in $C$. comosum (8\%). However, having high percentages (59.75\% and $54.13 \%$ ) of hydrocarbons and functionalised hydrocarbons respectively, C. comosum and C. arich could have a common ancestor. The second group is formed by $C$. azel. It is identified as different genetically from both species. In fact, the similarity was $18 \%$ and $11 \%$ for all and major chemical compound identified descriptors respectively. In fact, $C$. azel is the richest in sesquiterpenes hydrocarbons and oxygenated sesquiterpenes with $40.94 \%$ and $38.8 \%$ respectively. Also, C. azel presented viridiflorol (9.59\%) and $\alpha$-eudesmol (8.33\%) as the major oxygenated sesquiterpenes. The last was approximately twice more important in the essential oil of C. azel (38.8 \%) than that of $C$. comosum (15.42\%). Thus, the former could be considered as the chemotype of this oil. Furthermore, $C$. azel showed a small percentage of Carvacrol in its essential oil.

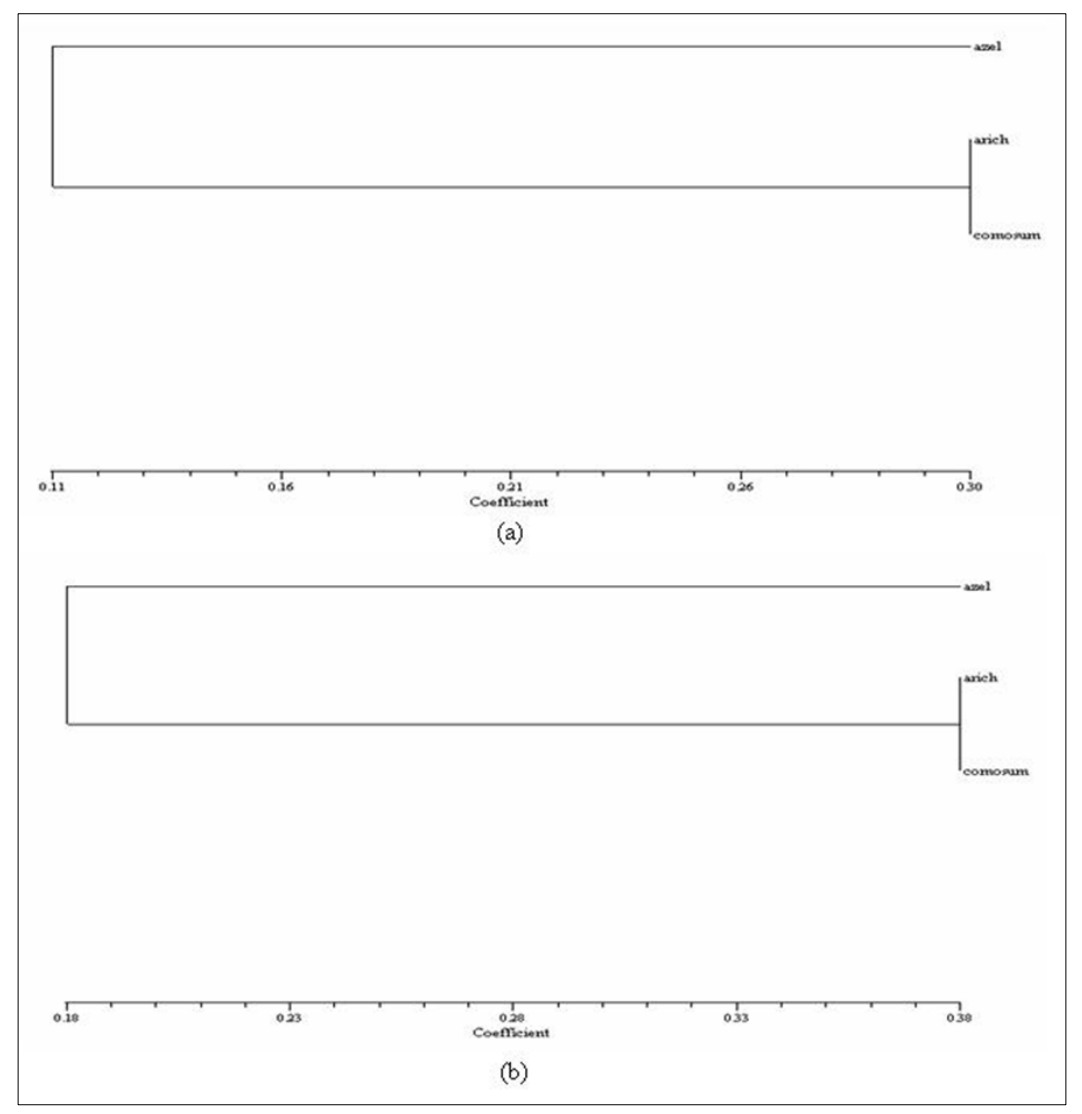

Figure 8 Cluster analysis of the three Calligonum species; (a): Dendrogram generated by the cluster analysis of the major chemical compound descriptors and (b): Dendrogram generated by the cluster analysis of all chemical compounds identified descriptors 
The GC and GC-MS analysis of these three oils (C. azel, C. comosum and C. arich) resulted in the identification of 64,36 and 19 constituents, respectively. So, the great difference in the number of constituents between species can be explained by the different positions of the studied species along the slope and its root distribution profile (fig. 9 and fig. 10). In fact, $C$. arich growing mostly on the upper part of the slope with a deep roots that can reach the ground water table and others very extended horizontal roots which exploit only surface soil water [3], while C. comosum exist in the foot of the slope (inter- dune) where there is always moisture on the soil surface [32]. So, these two species were less stressed and therefore they produce less secondary metabolites (19 and 36 constituents in arich and comosum oil respectively). In contrast, $C$. azel occurring mostly on the lower slope with only extended horizontal roots and more or less deep roots which face wind erosion [3]. For this reason, this species is often stressed and produce more secondary metabolites (64 constituents).

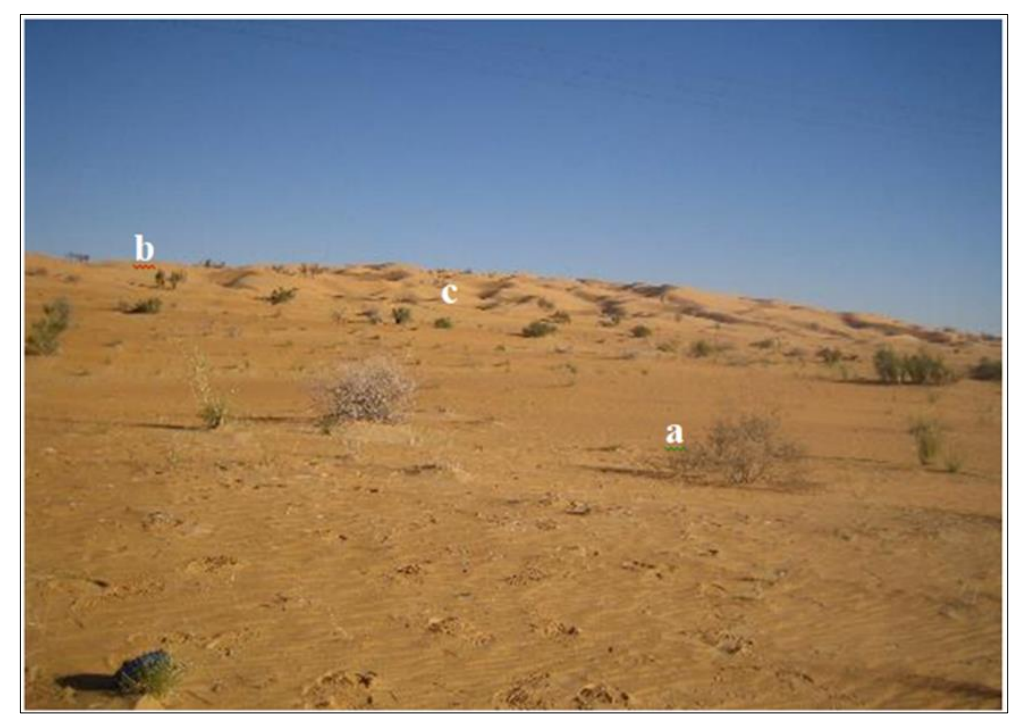

Figure 9 Photographs of El Borma site depicting the three Calligonum species in different slope positions: (b) C. arich in the upper slope, (a) C. comosum in foot slope and (c) C. azel in the lower slope

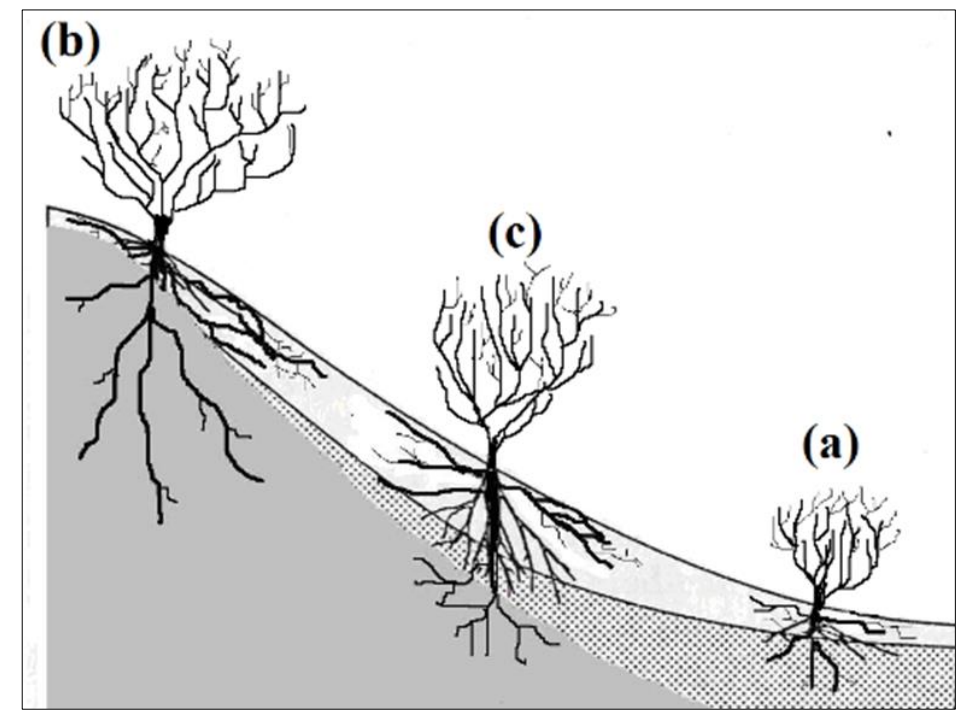

Figure 10 A Schema of Calligonum root depth in different slope positions in relation to soil moisture profile ((a): $C$. comosum, (b) : C. arich, (c) : C. azel ). White, speckled and gray painted areas among solid lines represent the dry soil layer, moist soil layer and bedrock, respectively, on the slope under drought

Plant diversity or existence of different morphological forms is an important phenomenon on which relies further progress in crop improvement. The characterization, classification and analysis of these morphological forms have become inevitable activities for assessing their genetic diversity [33]. In our study, it is worth mentioning that morphological similarities show two groups: the first one contains C. azel and C. comosum and the second group is 
formed by $C$. arich. Based on the chemical composition of the studied oils, two chemotaxonomic groups may be established: C. azel on one hand, $C$. arich and C. comosum on the other hand. As a consequence, the morphological diversity of the three studied species doesn't reflect their chemical polymorphism.

\section{Conclusion}

The essential oil composition of the three wild growing Calligonum species (C. comosum, C. azel and $C$. arich) from Tunisian deserts has not been reported before and therefore this study can be considered as the first information on the composition of essentials oils of the studied plant, indicating the existence of a chemical polymorphism in the genus Calligonum. The differences in essential oil composition detected between these species made the volatile fraction a reliable marker to distinguish between them and confirmed the phonological data at the base of their discrimination [15].

Further investigations are needed to reflect taxonomic relationships and chemical compositions of volatile compound in Calligonum, since its more than 80 species remain to be investigated.

\section{Compliance with ethical standards}

\section{Acknowledgments}

The authors are grateful to Professor Philip Simon for its constructive comments on earlier versions of the manuscript and Mr Fathi Magouri, chief of basis of the petrol station of El Borma (SITEP) for help to reside in this station. Mr Slah Zaidi, technician at the Institute of Arid Areas in Medenine is thanked for GC/MS analysis.

\section{Disclosure of conflict of interest}

No conflict of interest.

\section{References}

[1] Le Houérou HN. Recherches écologiques et floristiques sur la végétation de la Tunisie méridionale. Institut des Recherches Sahariennes, Alger. 1959.

[2] Dregne HE. Desertification of arid lands. In: El-Baz, F., Hassan, M.H.A. (Eds.), Physics of Desertification. Martinus, Nijhoff, Dordrecht, The Netherlands. 1986.

[3] Ozenda P. Flore et végétation du Sahara. CNRS Éditions, Première édition: 1977; 680.

[4] Thompson AE. Arid-land industrial crops. In: Janick, J., Simon, J.E. (Eds.), Advances in New Crops. Timber Press, Portland, Oregon. 1990; 232-241.

[5] Watt JM. Medicinal and poisonous plants of southern and eastern Africa. London: E and S Livingstone Ltd. 1962.

[6] MA Rahman, JS Mossa, MS Al-Said, MA Al-Yahya. Medicinal plant diversity in the flora of Saudi Arabia 1: a report on seven plant families. Fitoterapia. 2004; 75: 149-161.

[7] Le Floc'h. Contribution a une étude ethnobotanique de la Flore Tunisienne, Programme flore et végétation Tunisienne, deuxième partie. 1983; 402.

[8] M Okasaka, Y Takaishi, K Kogure, K Fukuzawa, H Shibata, T Higuti, G Honda, M Ito, OK Kodzhimatov, 0 Ashurmetov. New stilbene derivatives from Calligonum leucocladum. J. Nat. Prod. 2004; 7: 1044-1046.

[9] Cauvet C. Le chameau. pl. Librairie J. B. Baillière et fils, Paris. 1925; 1: 82.

[10] Ghazanfar SA. Handbook of Arabian medicinal plants. CRC press. 1984;

[11] Liu XM, Zakaria MNM, Islam MW, Radhakrishnan R, Ismail A, Chen HB, Chan K, Al-Attas A. Anti-inflammatory and anti-ulcer activity of Calligonum comosum in rats. Fitoterapia. 2001; 72: 487-491.

[12] Badria FA, Ameen M, Akl MR. Evaluation of Cytotoxic Compounds from Calligonum comosum L. Growing in Egypt, Z. Naturforsch. 2007; 62c: 656-660.

[13] Taia WK, El-Etaby MO. Taxonomical study in the desert plant Calligonum comosum L'Her. from two different locations in Saudi Arabia. Asian Journal of plant sciences. 2006; 5(4): 570-579. 
[14] Neffati M. Domestication des plantes spontanées autochtones à usages multiples en zones arides et désertiques (guide pratique de collecte, de conditionnement et de germination de leurs semences). Edité et publié par le centre d'information et de documentation des régions arides (CIDRA) - unité de publication, Institut des Régions Arides, Medenine, Tunisie. 2008; 198.

[15] Dhief A, Gorai M, Aschi-Smiti S, Neffati M. Comparative phenological and water potential patterns of three Calligonum species in the eastern great Erg of Tunisia. Flora. 2009; 204: 581-592.

[16] Pottier-Alapetite G. Flore de la Tunisie. Angiosperme-Dicotylédones : apétales-dialypétales-gamopétales. Ministère de l'Enseignement Supérieur et de la Recherche Scentifique et le Ministère de l'Agriculture, Tunis, Tunisie. 1979.

[17] Clevenger JP. Apparatus for the determination of volatile oil. J. Am. Pharmacol. Assoc. 1928; 17: $345-349$.

[18] Basar S, Koch A, Konig WA. A verticillane-type diterpene from Boswellia carterii essential oil. Flavour Fragr. J. 2001; 16(5): 315-318.

[19] Kovàts E. Characterization of organic compounds by gas chromatography. Part 1. Retention indices of aliphatic halides, alcohols, aldehydes and ketones. Helv. Chim. Acta. 1958; 41: 1915-1932.

[20] Adams RP. Identification of Essential Oil Components by Gas Chromatography / Quadrupole Mass Spectroscopy. Allured Publishing Corporation, Carol Stream USA. 2001.

[21] Asuming WA, Beauchamp PS, Descalzo JT, Dev BC, Dev V, Frost S, Ma CW. Essential oil composition of four Lomatium Raf. species and their chemotaxonomy. Biochem. Syst. Ecol. 2005; 33: 17-26.

[22] Oliveira DR, Leitão GG, Bizzo HR, Lopes D, Alviano DS, Alviano CS, Leitão SG. Chemical and antimicrobial analyses of essential oil of Lippia origanoides H.B.K. Food Chem. 2007; 101: 236-240.

[23] Mumm R, Tiemann T, Schulz S, Hilker M. Analysis of volatiles from black pine (Pinus nigra): significance of wounding and egg deposition by a herbivorous sawfly Phytochemistry. 2004; 65: 3221-3230.

[24] Rosselli S, Bruno M, Maggio A, Raccuglia RA, Bancheva S, Senatore F, Formisano C. Essential oils from the aerial parts of Centaurea cuneifolia Sibth. \& Sm. and C. euxina Velen., two species growing wild in Bulgaria. Biochem. Syst. Ecol. 2009; 37(4): 426-431.

[25] Ferhat MA, Tigrine-kordjani N, Chemat S, Meklati BY, Chemat F. Rapid Extraction of Volatile Compounds Using a New Simultaneous Microwave Distillation: Solvent Extraction Device. Chromatographia. 2007; 65: $217-222$.

[26] Phutdhawong W, Kawaree R, Sanjaiya S, Sengpracha W, Buddhasukh D. Microwave-Assisted Isolation of Essential oil of Cinnamomum iners Reinw. ex Bl.: Comparison with Conventional Hydrodistillation. Molecules. 2007; 12: 868-877.

[27] Sarouglou V, Dorizas N, Kypriotakis Z, Skaltsa HD. Analysis of the essential oil of eight Anthemis species from Greece. J. Chromatogr. A. 2006; 1104: 313-322.

[28] Yu Y, Huang T, Yang B, Liu X, Duan G. Development of gas chromatography-mass spectrometry with microwave distillation and simultaneous solid-phase microextraction for rapid determination of volatile constituents in ginger. Journal of Pharmaceutical and Biomedical Analysis. 2007; 43: 24-31.

[29] Bernard CB, Krishinamurty HG, Chauret D, Durst T, Philogene BJR, Sanchés- Vindas P, Hasbaun C, Poveda L, Roman LS, Arnason JT. Insecticidal defenses of Piperaceae from the neotropics. J. Chem. Ecol. 1995; 21: 801-814.

[30] Marongiu B, Maxia A, Piras A, Porcedda S, Tuveri E, Gonçalves MJ, Cavaleiro C, Salgueiro L. Isolation of Crithmum maritimum L. volatile oil by supercritical carbon dioxide extraction and biological assays, Natural Product Research. 2007; 21: 1145-1150.

[31] Jalšenjak V, Peljnjak S, Kuštrak D. Microcapsules of sage oil: essential oils content and antimicrobial activity. Biochem. Syst. Ecol. 1987; 42: 419-420.

[32] Evenari M, Shanan L, Tadmor N. The Negev. The Challenge of a Desert. Harvard University Press, Cam-bridge. 1982.

[33] Tiwari M, Singh NK, Rathore M, Kumar N. RAPD markers in the analysis of genetic diversity among common bean germplasm from Central Himalaya. Genet. Res. Crop Evol. 2005; 52: 315-324. 